\title{
DESCRIPTION AND MAPPING OF URBANIZATION DEVELOPMENT IN SUMATERA UTARA
}

\author{
Nurhanifah \\ Program Studi Komunikasi dan Penyiaran Islam, Fakultas Dakwah dan Komunikasi, \\ Universitas Islam Negeri Sumatera Utara \\ J1. Willem Iskandar Pasar V Medan, Sumatera Utara, 20371, Indonesia \\ e-mail: nurhanifah123@gmail.com
}

Received: 06 February 2020, Repaired: 03 July 2021, Approved: 04 August 2021

\begin{abstract}
Abstrak
Jumlah penduduk perkotaan terus meningkat setiap tahunnya akibat mobilitas penduduk dari desa ke kota (urbanisasi). Artikel ini bertujuan untuk mendeskripsikan perkembangan urbanisasi di Sumatera Utara. Metode penelitian yang digunakan adalah penelitian kepustakaan, pengumpulan data dilakukan dengan mengambil dari berbagai sumber seperti data BPS, jurnal, dokumentasi, dan ditambah dengan data observasi kemudian dianalisis secara deskriptif. Penelitian ini menemukan bahwa perkembangan penduduk Sumatera Utara (Sumatera Utara) masih terkonsentrasi di Kota Medan. Meski secara geografis hanya 0,36\% dari luas Sumatera Utara, Medan dihuni oleh 2.279.894 juta jiwa. Konsentrasi penduduk Sumatera Utara di Medan disebabkan oleh urbanisasi atau migrasi penduduk yang terus berlangsung dari desa ke kota. Tingginya jumlah penduduk perkotaan dapat menjadi masalah bagi pemerintah, salah satunya adalah munculnya fenomena kemiskinan, tunawisma, dan kemacetan. Seringkali orang yang pindah ke perkotaan memiliki alasan dan harapan yang besar seperti ingin mendapatkan pekerjaan, upah yang tinggi, gengsi, dan ingin menikmati fasilitas perkotaan. Kesimpulannya, perkembangan penduduk perkotaan di Sumatera Utara sejalan dengan pesatnya pembangunan infrastruktur, seperti jalan tol, dan industri yang dibangun oleh pemerintah, atau swasta terus berkembang. Meningkatnya tingkat urbanisasi menunjukkan semakin banyaknya penduduk yang tinggal di perkotaan (perkotaan) yang menyebabkan penduduk di perkotaan semakin padat. Banyaknya penduduk yang melakukan urbanisasi di Sumatera Utara disebabkan oleh faktor ekonomi dan sosial.
\end{abstract}

Kata Kunci: Urbanisasi, Pemetaan, Pembangunan, Sumatera Utara

\begin{abstract}
The number of urban residents continues to increase each year due to the mobility of the population from villages to cities (urbanization). Aims this article to describe the development of urbanization in Sumatera Utara. Method of research is library research, data collection is carried out by taking from various sources such as BPS data, journals, documentation, and coupled with observational data then analyzed descriptively. This research found that the population development of Sumatera Utara (Sumatera Utara) is still concentrated in Kota Medan. Although its geographical area is only $0.36 \%$ of Sumatera Utara's area, Medan is inhabited by 2,279,894 million people. The concentration of the population of Sumatera Utara in Medan is due to the ongoing urbanization or migration of people from villages to cities. The high number of urban residents can be a problem for the government, one of which is the emergence of the phenomenon of poverty, homelessness, and congestion. Often people who move to urban areas have big reasons and expectations such as wanting to get a job, high wages, prestige, and wanting to enjoy urban facilities. The conclusion is the development of the urban population in Sumatera Utara is in line with the rapid development of infrastructure, such as toll roads, and industries built by the government, or the private
\end{abstract}


sector continue to grow. The increasing level of urbanization shows the increasing number of people living in urban areas (cities) which causes the population to become denser in urban areas. The large number of people who urbanize in Sumatera Utara is due to economic and social factors.

\section{Keywords: Urbanization, Mapping, Development, Sumatera Utara}

\section{INTRODUCTION}

An area can experience changes along with the rate of population growth over time. One of the causes is due to movement, displacement, and demographic events such as births and deaths. In its development, the region has limitations in restraining the growth rate, especially the movement caused by urbanization (Purnama et al., 2020). People who mobilize have certain goals to carry out movements including economic motives, social motives and others (Achmad et al., 2019).

Of course, these conditions lead to new problems that must be resolved immediately. Indicators of population and population balance should be seen from the interrelation of the population with various development phenomena that are very broad (Harumain et al., 2021).

The balance indicator must be used as a guide and material to place these enormous human resources as development targets and at the same time as development actors. The classic problem of developing cities, increasing population, increasing land needs, both for settlements and other urban activities. Land as a natural resource is limited, human needs continue to increase, the availability of land becomes scarce and becomes an expensive economic commodity (Wilonoyudho et al., 2017).

The rapid development of the human population poses various challenges in various aspects of life (Bakri and Anita, 2018). Indonesia has undergone a rapid urbanization process with different characters in each region. This difference can also be seen in the type and distribution of cities that grow and develop in their area. This article is intended to analyze the differences in the urbanization process that occurs between regions in Indonesia, through understanding the differences in the growth of cities in each macro area in Indonesia. Urbanization in Indonesia has not been able to prosper the perpetrators and the areas that are the destination of urbanization. Every 1\% of urbanization growth in Indonesia is only able to increase the Gross Domestic Product (GDP) per capita by $4 \%$. The low economic benefits resulting from the phenomenon of urbanization in Indonesia in the end only turn the rural poor into urban poor. The level of urbanization has a positive relationship to per capita income and the number of urban poor people, on the other hand, the level of urbanization has a negative relationship to the number of rural poor people (Hadijah \& Sadali, 2020).

Urbanization today is not only seen as a process of moving people from rural areas to cities, urbanization describes the level of sacrifice or urbanity in a country or in an area, besides urbanization is also defined as a process of change from being rural to urban. The process of changing the nature of rural areas to urban areas is not limited to physical changes, namely changes in agricultural land to land with urban functions, but changes in every aspect of life that is rural into urban characteristics (Tatem \& Hay, 2004). Urban development will continue to occur in line with the development of population numbers and activities. Population growth has resulted in increased demand for land availability which will be used to carry out various activities.

Urbanization is a phenomenon experienced by big cities in Indonesia in particular. Urbanization occurs due to uneven regional growth, especially between hinterlands and urban areas (Yi et al., 2014). The greater the difference between the regional growth rates, the higher the level of urbanization. Expectations for a higher 
level of income are still very promising for urbanizers, even though in turn this urbanization will increase the population of the destination city (Piña, 2014). Most urbanization results from the natural increase in community activities (Leon, 2008).

This increase in population will then cause several problems for the destination city. The trend that occurs in the development of cities in third world countries, including Indonesia, is the rapid population growth, which often can no longer be properly anticipated by the carrying capacity of cities, especially in terms of providing living facilities for their citizens. The rapid population growth in the city is not only due to natural growth, but mainly due to urbanization. The increasing flow of urbanization seems to coincide with the number of economic centers being built in urban areas, especially in the industrialization sector (Purnama et al., 2020). Increasing urban population growth will cause various problems and bring consequences in all aspects of life in urban areas. The rate of urbanization occurring in Indonesia at this time is extraordinary, causing the city to grow very rapidly. Urban growth is mainly caused by various reasons such as the capitalization process, regional enlargement / reclassification, and migration from rural to urban areas(Alif et al., 2020). Urban growth causes many problems such as environmental damage, traffic jams, poverty, crime, and other social conflicts. The rapid rate of urbanization reflects the inequality between rural and urban development.

The lack of job opportunities in the villages causes residents to go to the cities in search of work. Inequality in development that occurs is the result of the implementation of a liberal economic system that only promotes growth, while on the other hand the agricultural sector is not paid any proper attention. Farmers are in a very weak position and do not have a good bargaining position, with very unequal exchange rates. Development inequality does not only occur between rural areas and cities, but also between Java and Java outside Java, and between western and eastern parts of Indonesia. A solution to this imbalance must be sought, with good management and fair development, including the political will to reform the economic system in favor of the government (Wilonoyudho, et al., 2017). Many big cities are in fact unable to provide more than minimal sanitation, health, housing, transportation, and employment services to some of the population. The consequence that arose later with the polarization was that many rural people, either voluntarily or forced, left the village where they were born and went to try their luck to find work in the city because of the narrower job opportunities available in the village. The author found a phenomenon where many productive people urbanize, with 3 various goals as stated by several figures above, although it can be said that they are urbanizing to increase life expectancy in the village, in fact this has a lot to affect development in abandoned villages. especially community-based development, where a lot of land potential is not exploited. This results in a lot of empty land and undeveloped abandoned villages(Yi et al., 2014).

Urban development will continue to occur in line with the development of population numbers and activities. Population growth has resulted in increased demand for land availability which will be used to carry out various activities. The increasing need for land will lead to competition among land users in the city. This is in accordance with the economic principle, that land users will always maximize their land use (Mohammed Hamud et al., 2019). Efforts to maximize land use will be reflected in the intensification of efforts to utilize land use. Activities that are considered unproductive and profitable will always be quickly replaced by other activities that are more productive and profitable (Mardiansjah and Rahayu, 2019).

The logical consequence of this phenomenon is the emergence of various 


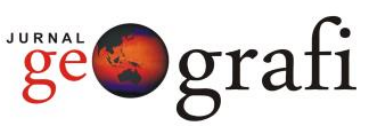

social problems in urban areas caused by the presence of immigrants with low socioeconomic characteristics. The helplessness of the economic condition of these people, in turn, gave birth to a social phenomenon that received much attention, both from government and academia. The visible social phenomenon is the emergence of certain communities, namely slum settlements, impoverished villages, and homeless people and beggars. This kind of phenomenon can be found in big cities such as Medan, Sumatera Utara. Rural communities around Sumatera Utara prefer to go to urban areas with the hope of getting a better income than in villages.

The flow of urbanization, especially towards the city of Medan and other cities around the city of Medan such as Pematang Siantar, Deli Serdang, and Binjai is getting bigger along with regional economic growth. Kota Medan, which is the capital of Sumatera Utara Province, is the right area according to rural residents around Sumatera Utara, especially to get a job. On the other hand, the available job opportunities, and business opportunities in the city of Medan including other cities in Sumatera Utara (Pematang Siantar, Deli Serdang, and Binjai) have not been able to accommodate urbanization actors due to the limited jobs available in the destination areas. Responding to this problem that continues to move dynamically, it is necessary to continuously study how the current development of urbanization in Sumatera Utara is so that the government can adopt a policy to reduce the rate of urbanization. Therefore, a study on urbanization is needed which aims to analyze the mapping and development of urbanization in Sumatera Utara.

\section{RESEARCH METHOD}

This type of research is a literature review study. Judging from the object and method of analysis used, this research is included in the type of literature study research. This type of research attempts to describe the description of urbanization development in Sumatera Utara. The data used in this study are secondary data from the Central Bureau of Statistics and the Geospatial Agency to analyze the patterns and movements of urbanization in Kota Medan. Coupled with data from observations, documents and. The technique used is descriptive analysis technique.

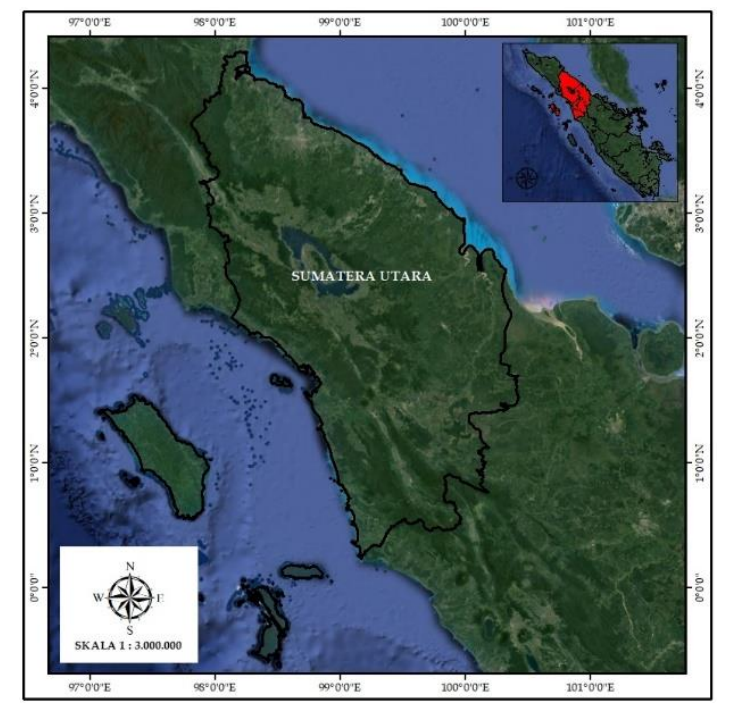

Figure 1. Research Map Location

\section{RESULTS AND DISCUSSION}

Urbanization has been seen as an integral part of economic growth (Elnagi et al., 2017). The World Bank (2018) states that urbanization can reduce poverty levels through an increase in Gross Domestic Product (GDP) per capita.

Like, the phenomenon of urbanization in China, Thailand, Vietnam, and India has significantly increased GDP per capita. For example, in India, every one percent $(1 \%)$ of urbanization growth can increase the value of GDP per capita by thirteen percent $(13 \%)$. In contrast to Indonesia, one percent $(1 \%)$ of urbanization growth is only able to increase the value of GDP per capita by up to four percent $(4 \%)$ (World Bank, 2018).

The low influence of urbanization on increasing per capita income in Indonesia indicates that urbanization has not been significant in the welfare of the perpetrators to be able to get out of poverty (Chen et al., 2019, in Hadijah, Z., \& Sadali, 2020) 
Urban areas around the world are increasingly facing the challenges of highly dynamic metropolitan growth, and at the same time, institutional changes such as decentralization and globalization. Such changes are evident in the peri-urban area, where urban and rural life meet (Seto, et al., 2011). Urban areas have become places for rapid physical, social and economic transformation (Woltjer, 2014). The underlying factors of urban growth are declining mortality, in the face of high and leading to high demographic growth (George Martine \& Gordon McGranahan, 2013).

Fact, urbanization has been shown to promote economic growth and improve people's livelihoods, but it can also increase energy consumption and further generate energy crises (Yabo Zhao and Shaojian Wang, 2015). The link between urbanization and development is of policy importance, especially in Africa and Asia. This paper reviews the arguments and evidence on whether rapid urban population growth can help raise living standards. The main finding is that the development effects of urbanization and the size of agglomeration economies vary widely. There is no simple linear relationship between urbanization and economic growth, or between city size and productivity.

The potential for urbanization to drive growth is likely to depend on how conducive infrastructure and institutional arrangements are. Removing barriers to rural-urban mobility allows economic growth, but the benefits will be far greater with supportive policies, markets, and infrastructure investment. Cities should use realistic population projections as a basis for investing in public infrastructure and implementing supportive land policies. Governments should find ways to enable forms of urbanization that contribute to growth, poverty alleviation, and environmental sustainability, rather than encouraging (or discouraging) urbanization per se (Turok, I and McGranahan, G., 2013).

\section{Overview of Sumatera Utara Province}

Sumatera Utara Province is located between 10-40 North Latitude and 980-1000 East Longitude. The total area of Sumatera Utara Province reaches $71,680.68 \mathrm{~km} 2$ or $3.72 \%$ of the territory of the Republic of Indonesia. Sumatera Utara Province has 162 islands, namely 6 islands on the East Coast and 156 islands on the West Coast. The borders of Sumatera Utara Province include Aceh Province in the north, Riau and West Sumatra Provinces in the south, the Indian Ocean in the west, and the Strait of Malacca in the east. The geographic location of Sumatera Utara Province is on the strategic route for international shipping in the Malacca Strait which is close to Singapore, Malaysia, and Thailand.

Topography The Sumatera Utara region consists of coastal areas, lowlands, and highlands as well as the Bukit Barisan mountains which stretch in the middle from North to South. The slope of the land is between $0-12 \%$ covering an area of $65.51 \%$ covering $8.64 \%$ and over $40 \%$ covering an area of $24.28 \%$, while the area of Lake Toba is 112,920 ha or $1.57 \%$. Based on its topography, Sumatera Utara is divided into 3 (three) parts, namely the eastern part, which is relatively flat, the middle part is wavy to hilly, and the western part is a wavy plain. The East Coast region, which is a lowland area of $24,921.99 \mathrm{~km} 2$ or $34.77 \%$ of the total area of Sumatera Utara, is a fertile area with high humidity and relatively high rainfall. This region has high economic potential, so it tends to be denser due to migration flows from the West Coast and highlands.

The highlands and the West Coast area covering $46,758.69 \mathrm{~km} 2$ or $65.23 \%$ of the total area of Sumatera Utara, which is mostly mountainous, has variations in the level of soil fertility, climate, topography, and contours as well as areas with unstable soil structure. Several lakes, rivers, waterfalls, and volcanoes are found in this area and some areas are recorded as areas of tectonic and volcanic earthquake 
Urbanization Development Data in Sumatera Utara

The population growth in Sumatera Utara has fluctuated every year due to population movements. One of them is caused by the flow of urbanization. The level of urbanization can be seen from the proportion of the urban population to the total population. Referring to (Gardiner \& Gardiner, 2006), in the context of Indonesia, there are two definitions of a city, namely, first, an administrative city in which an area (city) has an official urban status (city

Table 1. Urban and Rural Population

\begin{tabular}{lrrr}
\hline \multicolumn{1}{c}{ District } & Urban & Rural & Amount \\
\hline N i a s & 1.376 & 141.943 & 143.319 \\
Mandailing Natal & 75.358 & 371.929 & 447.287 \\
Tapanuli Selatan & 12.969 & 268.962 & 281.931 \\
Tapanuli Tengah & 103.396 & 273.271 & 376.667 \\
Tapanuli Utara & 31.980 & 269.809 & 301.789 \\
Toba & 45.678 & 138.034 & 183.712 \\
Labuhanbatu & 201.057 & 293.121 & 494.178 \\
A s a h a n & 287.985 & 441.810 & 729.795 \\
Simalungun & 305.733 & 562.189 & 867.922 \\
Dairi & 51.031 & 233.273 & 284.304 \\
Karo & 122.025 & 293.853 & 415.878 \\
Deli Serdang & 1.661 .312 & 534.397 & 2.195 .709 \\
L a n g k a t & 354.824 & 686.951 & 1.041 .775 \\
Nias Selatan & 9.745 & 310.157 & 319.902 \\
Humbang Hasundutan & 24.678 & 165.508 & 190.186 \\
Pakpak Bharat & 2.138 & 46.797 & 48.935 \\
Samosir & 12.076 & 114.112 & 126.188 \\
Serdang Bedagai & 247.122 & 369.274 & 616.396 \\
Batu Bara & 132.428 & 284.065 & 416.493 \\
Padang Lawas Utara & 15.110 & 257.603 & 272.713 \\
Padang Lawas & 29.981 & 251.258 & 281.239 \\
Labuhanbatu Selatan & 68.945 & 270.037 & 338.982 \\
Labuhanbatu Utara & 49.418 & 314.398 & 363.816 \\
Nias Utara & 3.381 & 134.586 & 137.967 \\
Nias Barat & 0 & 82.154 & 82.154 \\
S i b o l g a & 87.626 & & 87.626 \\
Tanjungbalai & 175.223 & 0 & 175.223 \\
Pematangsiantar & 255.317 & 0 & 255.317 \\
Tebing Tinggi & 164.402 & & 164.402 \\
M e d a n & 279.894 & 0.279 .894 \\
B i n j a i & 264.054 & 0.597 \\
Padangsidimpuan & 165.474 & 0.543 & 142.426 \\
Gunung Sitoli & 42.820 & 56.353 & 14.562 .549 \\
\hline Sumatera Utara & 7.284 .556 & 99.606 & \\
Source: Badan Pusat & 7.277 .993 & \\
\hline
\end{tabular}

Source: Badan Pusat Statistik Sumatera Utara, 2020. 
Based on the results of the 2020 Population Census (SP2020), the distribution of the population of Sumatera Utara (Sumatera Utara) is still concentrated in Kota Medan. Although its geographical area is only $0.36 \%$ of Sumatera Utara's area, Medan is inhabited by 2,279,894 million people. The concentration of the population of Sumatera Utara in Medan is due to the ongoing urbanization or migration of people from villages to cities. Referring to the results of SP2020, the distribution of the population of Sumatera Utara is the second largest in Deliserdang Regency as much as $1.66,312$ of the total population of Sumatera Utara. There are 7,284,556 urban residents and $7,277,993$ rural residents. This means that the number of urban residents is more than the rural population due to the mobility of the population from villages to cities. Then Simalungun Regency as many as 305,733 urban residents of the total population of Sumatera Utara. The next largest city is Binjai, with 264,054 urban residents. The high number of urban residents can be a problem for the government, one of which is the emergence of the phenomenon of poverty, homelessness, and congestion. Often people who move to urban areas have big reasons and expectations such as wanting to get a job, high wages, prestige and wanting to enjoy urban facilities.

However, in its implementation, most of the people who are mobile from village to city are not successful, so that it only adds to the burden on the government, giving rise to new phenomena such as slum settlements by utilizing railroad land and rivers as a residence. This happened because the city was not ready to accommodate additional residents and was unable to provide the necessary infrastructure. Slums generally a low-rise building with unhygienic services, sprawling in an urban environment. Vacant land occupied by slum dwellers, who do not have a permit. There's a trend in suburban area growth as well. Loss of agricultural land is an important issue. More and more land is freed for housing and agricultural land is sold for the same purpose. Another important reason for the loss of agricultural land is the use of excavated land from the land and sold for construction purposes as fill. That peasants try to make a profit by selling land causing environmental problems in turn. Land next door existing excavation plots are gradually eroded, causing (Hussain and Khan, 2013).

Of course, this phenomenon greatly disturbs the stability of the comfort of a city. Therefore, the government must be able to take policies to limit the flow of urbanization every year. As for the steps that can be taken by examining identity cards and deporting residents, if more than one year have not been able to get a job because it can affect labor statistics, namely increasing the number of unemployed in urban areas.

Besides that, the development of the urban population in Sumatera Utara is in line with the rapid development of infrastructure such as toll roads, industries built by the government, or the private sector continue to grow.

However, when examined from the conditions and problems faced by the Government, it has not been able to fully benefit from the increase in urban population. Although statistically any increase in urban population can affect the gross domestic product (GDP). Currently every $1 \%$ of urban population growth can increase GDP per capita by $1.4 \%$. This figure is very far from the growth of urban population in East Asia and the Pacific which has increased GDP per capita by $2.7 \%$, even China by $3 \%$

This shift shows that today the city plays an important role as a catalyst and center that can attract people to come and live. Cities have an important role to play in balancing territorial and rural development if they are well planned and managed.

Urbanization is often synonymous with the main city in an area as a location for capital accumulation, which is the main attraction for various economic activities. But the phenomenon of urbanization has not been able to restore the economy and 


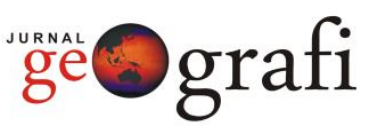

cannot guarantee the welfare of the community.

When viewed from the negative side, basically, graying has made the modern sector in urban areas much more productive than the traditional sector which is usually found in rural areas. For macro purposes, to increase national income. Therefore, it is proper that a less productive / unproductive workforce in rural areas should move to cities and work in the modern sector.

In aggregate, all of this workforce will contribute to total national income. Furthermore, the understanding of the negative impact that can be caused by urbanization is that rural areas (back areas) will lose their workforce, thus the agricultural sector will be hampered, due to the difficulty of finding work in rural areas (Danoedoro, 2019).

This condition will affect agricultural productivity to decrease. The wider impact will also affect industries that develop in cities that require rural agricultural products. If the influence is large for industry, then GNP growth will decline. This condition needs to be understood because thus urbanization must be controlled. If not, urbanization will create major problems that hinder the development process. Based on the risen migration figures from BPS, it is illustrated that since 1980, the number of people who left Sumatera Utara Province was more than those who entered. In other words, the annual net migration rate is always negative, and tends to increase.

The population density experienced by urban areas is one of the portraits that reflect the data on a large population occupying a very limited area. To see the phenomena and patterns of population mobility, experts use an analytical approach in four aspects, namely (1) spatial/spatial aspects, (2) residential aspects, (3) time aspects, and (4) social change aspects. By using the analytical approach referred to, the phenomenon of population mobility can be studied which has positive and negative implications for the main issues of
Available at http://jurnal.unimed.ac.id/2012/index.php/geo e-ISSN: 2549-7057 | p-ISSN: 2085-8167

population development and environmental carrying capacity (Utama, 2020).

Besides that, it is also important to increase economic efficiency in urban areas. Especially in the distribution of goods and services, support for adequate transportation infrastructure and facilities is needed. On the other hand, there is a limited capacity of the government, both central and regional, to build transportation infrastructure and facilities to accelerate regional development. Therefore, the challenges faced are increasing the availability and quality as well as expanding the range of basic infrastructure services, particularly clean water and electricity, as well as an integrated and optimal intermodal transportation system, by involving the coordinated business world. Development results in the social welfare sector in Sumatera Utara have shown progress and are better than the national average. Nevertheless, in this province, there are still disparities in welfare between economic groups and between regions, partly due to the limited reach of social infrastructure and facilities.

The above conditions present Sumatera Utara to the challenge of increasing, equalizing, and expanding the reach and quality of health services, education, and other social services, as well as the reach of information to all remote areas. The point is that it can limit the flow of urbanization because if good facilities and infrastructure are available in the area, it can discourage urbanization actors from moving to urban areas.

\section{Mapping of Urbanization Potential in Sumatera Utara}

Rapid urbanization has the potential to improve people's welfare. Although only about half of the world's population lives in cities, they produce more than 80 percent of the Global Domestic Product (GDP). Cities are also younger: home to relatively younger adults and of working age than rural areas, making them important places to gain a demographic advantage. But 
unfortunately, the modernization trend has now changed, so that many rural people want to make a fortune in the city. The government should have prepared a development scheme in rural areas with a trend that is not much different from the city so that the rate of urbanization can be suppressed.

If the government only deals with the impact of urbanization with justice operations after Eid or certain moments do not solve the problem. Therefore, the central government and local governments must jointly promote the rural economy. Besides that, the government must be able to build the economy by building quality schools, training in skills, and developing business potential in rural areas (Amri et al., 2018).

The high level of urbanization is an indicator of population pressure in an area. The high level of urbanization in an area is usually expressed by the number of urban (urban) residents divided by the total number. The rate of urbanization in Sumatera Utara in the 2005-2015 period tended to increase for 10 years.

Table. 2 Urbanization Rate in Sumatera Utara

\begin{tabular}{ccc}
\hline No. & Year & $\begin{array}{c}\text { Urbanization } \\
\text { Rate }\end{array}$ \\
\hline 1. & 2005 & $43,2 \%$ \\
2. & 2006 & $45,1 \%$ \\
3. & 2007 & $45,3 \%$ \\
4. & 2008 & $45,4 \%$ \\
5. & 2009 & $45,7 \%$ \\
6. & 2010 & $49,1 \%$ \\
7. & 2011 & $49 \% \%$ \\
8. & 2012 & $49,5 \%$ \\
9. & 2013 & $49,1 \%$ \\
10, & 2014 & $49,2 \%$ \\
11. & 2015 & $51,9 \%$ \\
\hline
\end{tabular}

Source: Badan Pusat Statistik, 2018

The increasing level of urbanization shows the increasing number of people living in urban areas (cities) which causes the population to become denser in urban areas. The large number of people who urbanize in Sumatera Utara is due to economic and social factors. Most people want higher wage rates and more decent work in urban areas than in rural areas. Moreover, in the capital city, it has become a destination for urbanites to migrate which is used as a new place for fortune. The urbanization of Sumatra per year is estimated to grow up to $3.5 \%$. The demand for housing is getting higher while the land, especially in the city of Medan, is inadequate. Over time, the increasing urbanization process in Sumatera Utara from year to year will become a problem, especially in the increasing population. But urbanization can occur due to development in urban areas, so that rural development is also needed so that the population is evenly distributed between urban and rural areas (Amelia, 2018).

The urbanization process can be linked to the development process. The urbanization process is taking place at a rapid rate in Sumatera Utara, changing its landscape by extending it to the rural-urban suburbs where urban urbanization patterns are scattered. This high expansion results in social and environmental costs that increase social inequality and unequal provision of infrastructure, services and urban areas (Sariffuddin et al., 2017).

So far, the government has responded to urbanization, especially after Eid. The Sumatera Utara government has responded to the flow of urbanization by conducting administrative outreach for new migrants. Socialization is carried out by appealing to newcomers to report to the Dukcapil Office for data. Their socialization target is the immigrants who are allegedly many in industrial and densely populated areas.

The operations of Justisi and Binduk that have been carried out so far are considered weak in overcoming the problem of urbanization. This is because the Justisi operation only records residents who have a population document in the form of $\mathrm{KTP}$, and for those who do not have a KTP in the destination area of urbanization, immigrants are only required to have 


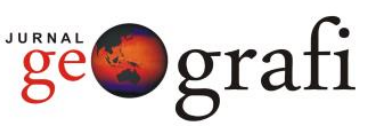

housing guarantees. Village local governments - as abandoned areas - do not seem to see the problem of urbanization as local problems. As a result, the response given to the phenomenon of urbanization is less visible.

The decision to urbanize seems to be considered a personal decision so that it is not responded to as a regional problem. Urbanization basically arises because rural areas are unable to provide decent jobs for their citizens. Meanwhile, big cities promise jobs and various facilities that are expected to provide a decent and even prosperous life. However, on the other hand, the competence of humans who urbanize to the city is not prepared. Apart from not having competence, migrants do not have a certain amount of funds to guarantee life if they have not found a job in the city. Even the newcomers had no idea the work to be done.

This has contributed to the emergence of various urbanization problems. The city government currently only sees the problem of urbanization as a single problem, namely the problem of moving people from villages to cities, which requires adjustments in terms of population administration. In fact, the impact of urbanization in Indonesia has caused problems, not only in destination cities but also in abandoned areas. In a public policy perspective that views urbanization as a complex problem and must be resolved in a systemic manner, the participatory method is the right method to solve the problem of urbanization. The central government can become a facilitator to put regional heads together and find a common thread on what is the problem related to urbanization in their respective regions.

Thus, it is hoped that there will be a common understanding, that the problem of urbanization is not only a personal problem of the community and not only a matter of population administration. Urbanization is a common problem that is generated at both the upstream and downstream levels. Therefore, solving the problem of urbanization must be done comprehensively and thoroughly. Policies in overcoming urbanization problems must be comprehensive, both for individuals and local governments, both in cities and villages. Individuals must be prepared for their competence. The region must provide the jobs that its citizens need. Of course, infrastructure that supports the comfort of residents in carrying out their activities must also be considered. Urbanization is a phenomenon that continues to occur, especially after Eid. From a public policy perspective, the government's response so far has shown that the problem of urbanization is still seen as a matter of population administration alone. In fact, urbanization is a complex problem, which requires a systemic solution. Systematic problem solving must be started by involving the participation of all stakeholders, both community members and local government in cities and villages. Involving the community and local government in a discussion forum on urbanization will be able to unravel the various causes and consequences of urbanization, so that a comprehensive solution can be found. Without a comprehensive solution, the problem of urbanization will become an annual problem that is always discussed but never gets a comprehensive solution (Katharina, 2017).

\section{CONCLUSION}

Most people want higher wage rates and more decent work in urban areas than in rural areas. Moreover, in the capital city. it has become a destination for urbanites to migrate which is used as a new place for fortune. The urbanization of Sumatra per year is estimated to grow up to $3.5 \%$. The population of Sumatera Utara (Sumatera Utara) is still concentrated in Kota Medan. Although its geographical area is only $0.36 \%$ of Sumatera Utara's area, Medan is inhabited by $2,279,894$ million people. The concentration of the population of Sumatera Utara in Medan is due to the ongoing urbanization or migration of people from 
villages to cities. The high number of urban residents can be a problem for the government, one of which is the emergence of the phenomenon of poverty, homelessness, and congestion. Often people who move to urban areas have big reasons and expectations such as wanting to get a job, high wages, prestige, and wanting to enjoy urban facilities. In addition, the development of the urban population in Sumatera Utara is in line with the rapid development of infrastructure, such as toll roads, and industries built by the government, or the private sector continue to grow. The increasing level of urbanization shows the increasing number of people living in urban areas (cities) which causes the population to become denser in urban areas. The large number of people who urbanize in Sumatera Utara is due to economic and social factors.

\section{REFERENCES LIST}

Amelia. (2018). Analisis Faktor-Faktor yang Mempengaruhi Tingkat Urbanisasi di Sumatera Utara. Skripsi. Medan; Program Studi Strata-I Ekonomi Pembangunan Fakultas Ekonomi dan Bisnis Universitas Sumatera Utara

Bakri, M and Anita Kasim, A. (2018). The Urban Planning Concept Based on Smart City Approach. Livas: International Journal on Livable Space, 3 (2), 63-70

BPS. (2020). Badan Pusat Statistik Sumatera Utara

Central Bureau of Statistics, Indonesia

George Martine \& Gordon McGranahan (2013) The legacy of inequality and negligence in Brazil's unfinished urban transition: lessons for other developing regions, International Journal of Urban Sustainable Development, (5), 1, 7-24.

Hadijah, Z., \& Sadali, M. I. (2020). Pengaruh urbanisasi terhadap penurunan kemiskinan di Indonesia. Jurnal Wilayah dan Lingkungan, 8(3), 290306.
Hussain and Khan. (2013). A Sustainable Approach to Urbanization. International Journal of Scientific Research, 2, (7), 1-4.

Katharina. R.B. (2017). Respons Atas Fenomena Urbanisasi Dalam Perspektif Kebijakan Publik. Majalah Info Singkat, 9, (13), 17-20

Mardiansjah, H.F dan Rahayu, P. (2019). Urbanisasi dan Pertumbuhan KotaKota di Indonesia: Suatu Perbandingan Antar Kawasan Makro Indonesia, Jurnal Pengembangan Kota, 7 (1), 91-110.

Mustafa Elnagi Elsamani Hassan and Agus Joko Pitoyo. (2017). Urbanization And Economic Development in Indonesia: Demographic Perspectives Analysis. Populasi, 25, (2), 54-69

Piña, A.W. (2014). Urbanization: concepts, trends, and analysis in three Latin American cities. Miscellanea Geographica - Regional Studies on Development, 18, (3), 5-15.

Seto, C.K., et al., (2011). A Meta-Analysis of Global Urban Land Expansion. PLoS ONE, 6 (8), 1-9

Turok, I and McGranahan, G. (2013). Urbanization And Economic Growth: The Arguments and Evidence for Africa and Asia. Journal of Environment \& Urbanization, 25(2): 465-482.

Utama, I. (2020). Analisis Tekanan Penduduk Terhadap Lingkungan Hidup Provinsi Sumatera Utara. Jurnal Manajemen Bisnis, 33 (1), 1-22.

Wilonoyudho, S., Rijanta, R., Keban, T.Y and Setiawan, B. (2017). Urbanization and Regional Imbalances in Indonesia. IJG Vol. 49, (2), 125-132

Woltjer, J. (2014). A Global Review on PeriUrban Development and Planning. Jurnal Perencanaan Wilayah dan Kota, 5 (1), 1-16.

Yabo Zhao and Shaojian Wang. (2015). The Relationship between Urbanization, Economic Growth and Energy Consumption in China: An 
Econometric Perspective Analysis. 7, 5609-5627.

J. S. Setyono, H. S. Yunus, and S. R. Giyarsih. (2016). "The Spatial Pattern of Urbanization and Small Cities Development in Central Java: A Case Study of SemarangYogyakarta-Surakarta Region," Geoplanning: Journal of Geomatics and Planning, vol. 3, no. 1, pp. 5366, Jun. 2016.

Achmad, A., Sari, L. H., \& Ramli, I. (2019). A study of urban heat island of Banda Aceh City, Indonesia based on land use/cover changes and land surface temperature. Aceh International Journal of Science and Technology, 8(1), 41-51.

Alif, S. M., Yosua, E., Fauzi, A. I., \& Leksono, B. E. (2020). Association between Surface Air Temperature And Land Use On The Campus Scale. Journal of Geoscience, Engineering, Environment, and Technology, 5(3), 161-169.

Amri, S. N., Adrianto, L., \& Bengen, D. G. (2018). Spatial Projection of Land Use and Its Connection With Urban Ecology Spatial Planning in the Coastal City, Case Study in Makassar City, Indonesia. International Journal of Remote Sensing and Earth Sciences (IJReSES), 14(2), 95.

Danoedoro, P. (2019). Multidimensional landuse information for local planning and land resources assessment in Indonesia: Classification scheme for information extraction from high-spatial resolution imagery. Indonesian Journal of Geography, 51(2), 131-146.

Harumain, Y. A. S., Nordin, N. A., Ching, G. H., Zaid, N. S., Woodcock, A., Mcdonagh, D., \& Faiz, K. (2021). The urban women travelling issue in the twenty-first century. Journal of Regional
Available at http://jurnal.unimed.ac.id/2012/index.php/geo e-ISSN: 2549-7057 | p-ISSN: 2085-8167

and City Planning, 32(1), 1-14.

Leon, D. A. (2008). Cities, urbanization and health. International Journal of Epidemiology, 37(1), 4-8.

Mohammed Hamud, A., Mobarak Prince, H., \& Zulhaidi Shafri, H. (2019). Landuse/Landcover mapping and monitoring using Remote sensing and GIS with environmental integration. IOP Conference Series: Earth and Environmental Science, 357(1).

Purnama, H., Gunarto, T., \& Budiarty, I. (2020). Effects of energy consumption, economic growth and urbanization on indonesian environmental quality. International Journal of Energy Economics and Policy, 10(6), 580-587.

Sariffuddin, S., Wahyono, H., \& Brotosunaryo, B. (2017). Street Vendors Hypergrowth: Consequence of Uncontrolled Urbanization In Semarang City. KOMUNITAS: International Journal of Indonesian Society and Culture, 9(1), 81-91.

Tatem, A. J., \& Hay, S. I. (2004). Measuring urbanization pattern and extent for malaria research: A review of remote sensing approaches. Journal of Urban Health, 81(3), 363-376.

Wilonoyudho, S., Rijanta, R., Keban, Y. T., \& Setiawan, B. (2017). Urbanization and regional imbalances in Indonesia. Indonesian Journal of Geography, 49(2), 125-132.

Yi, K., Tani, H., Li, Q., Zhang, J., Guo, M., Bao, Y., Wang, X., \& Li, J. (2014). Mapping and evaluating the urbanization process in northeast China using DMSP/OLS nighttime light data. Sensors (Switzerland), 14(2), 3207-3226. 